\title{
Giovanna Fossati
}

From Grain to Pixel - The Archival Life of Film in Transition

Amsterdam (Amsterdam University Press) 2009, 320 p., € 39,50, ISBN 978908964 I39 7

Fossati schetst filmhistorici en filmarchivarissen als twee beroepsgroepen die weinig van elkaar weten en weinig met elkaar praten. Zonder dat ze in verwijten wil vervallen, kan ze toch constateren dat aan de ene kant veel filmwetenschappers nog nooit een filmblik hebben opengetrokken en dus de walm van nitraat niet kennen uit eigen ervaring, en dat aan de andere kant veel filmarchivarissen zich nog nooit grondig verdiept hebben in het theoretische debat. Dit beeld valt uiteraard enigszins te nuanceren. Zo is internationaal gezien pionier Jerzy Toeplitz een vroege uitzondering (hij was directeur van het Poolse filmarchief en tevens 
filmhistoricus) en is in Nederland de communicatie tussen filmarchief en filmwetenschap gestart in de jaren tachtig met bijvoorbeeld de rubriek 'Weergevonden', geschreven door archiefmedewerkers van het Filmmuseum en gepubliceerd in onder andere GBG-nieuws. De staf van het Filmmuseum heeft deze lijn van voorlichting sindsdien voortgezet en uitgebouwd. Fossati is zelf een van de prominente krachten in dit collectief van bruggenbouwers, die met hun werk een verbinding slaan tussen de wereld van filmarchieven en de filmwetenschap. Een meer institutionele bundeling van krachten gebeurt in de serie seminars van Archimedia, een Europees opleidingsprogramma dat sinds 1997 bestaat. Zo werd in januari 2003 in Amsterdam het seminar 'Film Archives in the Digital Era: New Concepts and New Policies' gehouden. Deze bijeenkomst vormde een inspiratiebron voor het onderzoek van Fossati. Ze kon hierbij ook voortbouwen op het werk van andere Nederlandse promovendi die eveneens beschouwd kunnen worden als bruggenbouwers tussen filmarchief en filmwetenschap, zoals bijvoorbeeld Ivo Blom en meer recent Bregt Laméris. Toch is de constatering terecht dat we nog steeds te maken hebben met twee gescheiden werelden. De filmhistorici treffen elkaar bij de Domitor-congressen, terwijl de filmarchivarissen elkaar treffen bij de FIAF-congressen. De dringend noodzakelijke kruisbestuiving vindt voornamelijk informeel plaats, bijvoorbeeld tijdens de festivals van Pordenone, Bologna of de Biënnale van het Filmmuseum.

Film maakt onderdeel uit van een bredere context, een medialandschap dat door de digitalisering van het beeld in verandering is (het trefwoord hierbij is 'transition'). Filmarchieven zijn onder invloed van de eisen van de tijd volop in een veelzijdig veranderingsproces verwikkeld: onder andere op het vlak van toegankelijkheid en presentatie, maar ook hun collectie verandert. Filmerfgoed was lange tijd exclusief bestemd voor vertoningen in de filmzaal, maar deze dominantie van het publieke domein is voorbij. Filmerfgoed heeft een hybride positie gekregen, want het kan ener- zijds nog steeds zichtbaar gemaakt worden in de publieke ruimte, maar het is anderzijds ook beschikbaar in het privédomein en het kan eveneens onderdeel zijn van een virtuele wereld. Daarnaast heeft het filmerfgoed een veelsoortige fysieke verschijningsvorm, variërend van de traditionele 'dispositief van de projectie in een filmzaal, tot het oproepen van een computerbestand in een individuele multimedia-omgeving. De aard van de beelddrager kent een ontwikkelingslijn van analoog, via elektronisch naar digitaal, maar verwarrend genoeg bestaan momenteel deze drie opties gelijktijdig naast elkaar.

Fossati onderzoekt de veranderingen in de archiefpraktijk in de periode I997-2007. Ze geeft dus een analyse van het recente verleden en een reflectie op de actuele situatie in de wereld van filmarchieven, filmlaboratoria, Europees filmbeleid en filmwetenschap. Ze onderscheidt vier mogelijke gedachtekaders in de wereld van de filmarchieven: 'Film as Original', 'Film as Art', 'Film as Dispositif en 'Film as State of the Art'. Dit combineert ze met de doorlichting van drie sleutelbegrippen uit de filmwetenschap: 'Convergence/Divergence', 'Remediation' en 'Simulation'. In het laatste hoofdstuk illustreert ze dit theoretische bouwwerk aan de hand van vijf casestudies van recente filmconserveringen. Haar onderzoek heeft een sterk praktische inslag, want de verworven inzichten worden nuchter en helder verwoord en meteen uitgetest in een concrete toepassing.

Fossati stelt onder andere urgente vragen over het collectiebeheer, met als eerste symptoom het dilemma rondom de definitie van 'het origineel'. In de bioscoop is de filmkopie een onderdeel van een oplage van beelddragers, een serie van identieke exemplaren die bestemd zijn voor internationale roulatie binnen het systeem van commerciële exploitatie. In het filmarchief is de filmkopie een authentiek voorwerp, een museaal artefact, onderdeel van de collectie filmerfgoed. Lange tijd had de filmkopie de vorm van een filmstrook verpakt in filmblikken, het was een zichtbaar en tastbaar voorwerp. Digitalisering bracht een ver- 
schuiving naar ongrijpbare computerbestanden en 'bit streams'.

Een soortgelijke discussie doet zich voor bij de restauratie van moderne beeldende kunst. Voor een actueel overzicht van het debat is te wijzen op het proefschrift van Vivian van Saaze Doing Artworks: A study into the presentation and conservation of installation artworks (Universiteit Maastricht, 27 december 2009). Continuiteit is gewaarborgd, want de promovenda is betrokken bij het onderzoeksprogramma 'New strategies in conservation of contemporary art', een samenwerking tussen het Instituut Collecties Nederland, de Universiteit Maastricht en de Universiteit van Amsterdam.

In een goed afgebakend en gestructureerd betoog bouwt Fossati voort op de theoretische inzichten van onder anderen William Uricchio en Henry Jenkins. Ze schaart zich ook in een reeks van promovendi rondom hoogleraar Frank Kessler. We kunnen onderhand spreken van een 'Utrechtse school' die zich door de jaren heen aan het formeren is. Het is een gevarieerd gezelschap dat uitwaaiert over de academische wereld en de archiefwereld, met als gemeenschappelijk kenmerk een grote interesse in de context van de (vroege) cinema. Het proefschrift van Fossati verscheen meteen in een internationale handelseditie: From Grain to Pixel is de eerste publicatie in de reeks Framing Film, een samenwerkingsverband tussen het Filmmuseum en de Amsterdam University Press. Het is een goede start van deze reeks, want de contouren van het onderzoeksprogramma zijn duidelijk en systematisch uitgestippeld.

Peter Bosma 